\title{
SISÄÄN LASKEMISEN JA POIS SULKEMISEN RAJAMAILLA: Kriittinen näkökulma marginaalisuus- termin käyttöön
}

Vuonna 2017 olemme juhlineet Suomen itsenäistä historiaa. Suomi 100 -teema on levittäytynyt kaikkiin kuviteltavissa oleviin, ja hyvin mielikuvituksellisiinkin, yhteyksiin. Lähikuvakin kantaa oman kortensa kekoon ja vuoden kolmas numero keskittyy suomalaisuuteen. Toimituskunnan pohtiessa, millä tavalla lähestyisimme aihetta, mietimme vaihtoehtoja aina kotimaisen elokuvan historiasta tulevaisuuden kuvauksiin. Päädyimme kysymään, mikä on sellaista suomalaisuutta, jota syystä tai toisesta asetetaan marginaaliseen rooliin, ja miten audiovisuaalisessa kulttuurissa on käsitelty, tuotettu tai kyseenalaistettu marginaalisuutta.

Vuoden aikana on käyty jo monenlaisia keskusteluja siitä, millaiset asiat määrittävät suomalaisuutta, ja yhtenä toistuvana teemana on ollut pohtia sukupuolten esittämisen pinttyneitä kulttuurisia tapoja. Esimerkiksi Helsingin Sanomat nosti esille, miten syksyn laajassa elämäkertavalikoimassa (62 opusta) ainoastaan kuudessa keskitytään naisiin. Samaisessa artikkelissa tuodaan esille, miten juhlavuonna sukupuolijakauma on aiempaa suurempi. (Kanerva 2017.) Huomio herätti keskustelua sosiaalisessa mediassa, jossa pohdittiin, koetaanko miesten tarinat enemmän juhlavuoden arvoisina ja milloin olisimme yhteiskuntana tilanteessa, jossa naisten ja muiden sukupuolien saavutukset voisivat yhtä lailla edustaa kansallisia saavutuksia, muistia ja identiteettiä.

Samoin huomiota herätti Vuosisadan suomalainen -stand up -show! -kiertue. Koomikko Iikka Kivi (2017) kertoi Facebook-sivuillaan jättäytyvänsä pois kiertueelta sen all male panel -luonteen vuoksi. Vuosisadan suomalaisuutta olivat päässeet edustamaan vain mieskoomikot. Runsaan kritiikin vuoksi järjestäjät lisäsivät jälkikäteen mukaan naiskoomikoita, mutta lähtökohdat pakottavat huomaamaan, miten oikeus keskustella suomalaisuudesta on usein valitettavan sukupuolitettua.

Lähikuvan marginaalisuus-numero kiinnittyy näihin keskusteluihin mielenkiintoisella tavalla. Marginaalisuutta on käsitelty tyypillisesti koulutuksen, talouden, politiikan, terveyden, psykologisen ja sosiologisen tutkimuksen kentillä, jolloin huomiota on kiinnitetty sosiaaliseen poissulkemiseen, syrjintään ja syrjäytymiseen (ks. esim. Dennis 2005). Lisäksi sitä on yhdistetty maantieteelliseen ja erityisesti jälkikoloniaaliseen keskusteluun, jolloin huomion kohteeksi ovat nousseet kysymykset epätasa-arvosta ja monikult- 
tuurisuudesta (ks. esim. Ferguson et al. 1990; Lee 1995; Chand, Nel \& Pelc 2017). Kun toimituskunnan kanssa pohdimme kirjoittajakutsua, näimmekin mielessämme keskusteluja erilaisista vähemmistöryhmistä. Lopputuloksessa vähemmistöryhmät ovat myös läsnä, mutta keskusteluiden pääpaino on suomalaisten (miesten) suhteessa työntekoon. Suomessa ihmisen arvoa on kenties liiaksikin laskettu työteliäisyyden varaan, ja siksi työnteon ulkopuolelle joutuminen - esimerkiksi työttömyyden tai eläköitymisen kautta - saattaa aiheuttaa sosiaalista poissulkemista.

Se, että monessa tämänkin numeron teksteissä marginaalisuuden kokemuksia käsitellään erityisesti miesten kautta, nostaa esille kysymyksen, koetaanko Suomessa sosiaalinen eristäminen ja eristäytyminen erityisen ongelmallisena miesten kohdalla. Suomessa julkinen marginaalisuuspuhe keskittyy usein syrjäytymiseen, ja erityisen huolestuneita ollaan nuorten miesten kohtaloista (esim. Yle 2017). Tällöin huomio kiinnittyy siihen, miten sosiaaliset, poliittiset, taloudelliset, fyysiset ja ympäristölliset tekijät vaikuttavat ihmisen kykyyn ja mahdollisuuteen olla osallisena. Suomalaisen mieheyden kertomuksen kannalta ongelmallista on se, että julkisessa keskustelussa painotetaan henkilökohtaisia kykyjä, jolloin syrjäytymisestä tehdään yksilöiden ongelma ja osa yksilöille ylhäältä annettua ja oletettua identiteettiä. Jos miesten epäonnistumisista tai puutteista kansalaisina luodaan mittapuu kulttuurin marginaaleille, jätetään naiset, ja muutkin suomalaisen mieheyden tarinaan sopimattomat ryhmät, näkymättömäksi, ja samalla asetetaan kohtuuttomia menestysvaatimuksia miehille.

Sukupuoliasetelmaa voidaan kuitenkin lähestyä myös toisesta näkökulmasta, jossa ei niinkään määritellä, mitä marginaalisuus on, vaan kysytään, kuka on marginaalissa ja kenen näkökulmasta, miten se ilmenee ja mitkä ovat marginaalisuuden seuraamukset ja syyt (ks. Pelc 2017, 26). Tällöin huomio ei kiinnity identiteettiin vaan sosiaaliseen, historialliseen ja poliittiseen prosessiin, jossa neuvotellaan marginaalin ja keskiön välillä ja jossa samalla keskustellaan myös rajoista kunniallisen ja poikkeavan välillä. Tämä näkökulma nostaa esille, miten marginaalisuus voi paitsi syrjäyttää myös luoda tiloja toimijuudelle ja keskuksen toimintatapojen haastamiselle. (Rodríquez Garzia \& Lauro 2016.)

Kotimaisen marginaalisuuskokemuksen keskittyminen siihen, miten syrjäydytään - eli miten keskuksesta ajaudutaan pois - osaltaan selittää, miksi keskustelu tuntuu usein kääntyvän miehiin. Jos kulttuurisesti oletetaan miesten olevan keskiössä, on sieltä pois joutuminen kohtalokasta. Sen sijaan, jos huomioisimme marginaalit osana myös toiseen suuntaan liikkuvaa prosessia, jossa syrjinnän keinoja haastetaan ja luodaan uudenlaisia toimijuuksia, syntyisi termille kenties uusia käyttöyhteyksiä.

Onkin mielenkiintoista verrata Marginaalien Suomi -kokonaisuutta aiempaan kuulumista käsitelleeseen numeroon (Lähikuva 2016:4), jossa kuulumisen kokemusta analysoitiin maahanmuuttajien, tyttöjen seksuaalisuuden ja luokan sekä sukupuolikonfliktien kautta. Keskuksen ja marginaalisuuden rajat näyttäytyivät eri tavalla, kun samantyylistä aihepiiriä lähestyttiin eri käsitteellä. Jenni Hokan (2014) mukaan kuulumisen politiikka liittyy juurikin siihen, ketkä kuuluvat yhteen, millaisia kuulumisen yhteisöjä on ja ketkä jäävät näiden ulkopuolelle.

Sekä marginaalisuuden että kuulumisen käsitteet puhuvat siis sisään laskemisesta ja ulos sulkemisesta, mutta marginaalisuus tuntuu suuntaavan huomion liikkeeseen keskustasta pois ja kuuluminen puolestaan liikkeenä (tai toiveena) kohti keskustaa. Tämä ero johtaa myös marginaalisuus-termin 
sukupuolittuneeseen käyttöön. Miehiä käsitellään enemmän syrjäytymisen diskurssin kautta ja naisia (ja monia muita vähemmistöryhmiä) käsitellään puolestaan näkyväksi tekemisen kautta. Kenties näillä käsitteiden käytöillä paitsi julkinen puhe myös tutkimus tulee omalta osaltaan uudelleen tuottaneeksi yhteiskunnallisia rakenteita ja käytänteitä.

Millaisia marginaalisuuksia numeron teksteissä on sitten käsitelty? MikkoOlavi Seppälä tutkii Nyrki Tapiovaaran elokuvaa Varastettu kuolema (1938) poliittisena kommenttina 1930-luvun vasemmistolaisesta aktivismista. Hän pohtii, miten roolitus elokuvanteossa suhteutui aikakauden poliittisiin jännitteisiin ja miten työväen aktiivinen toiminta näyttäytyi ongelmallisena erityisesti viranomaisten ja valtiovallan näkökulmasta. Artikkelin näkökulman mukaan valtiokoneiston käytännöt ja odotukset kunniallisesta kansalaisuudesta tuottavat marginaalisia asetelmia, mutta Seppälä korostaa, että ironian avulla elokuvantekijät myös kritisoivat näitä käytänteitä. Artikkeli osoittaa, miten poliittinen marginaalisuus voidaan nähdä aktiivisena tilana ja toimijuutena.

Ongelmallisempana sen sijaan näyttäytyy marginaalisuuden suhde työntekoon, ja erityisesti 1990-luvun lama-aika jätti syvät jäljet kansakunnan kertomuksiin. Miina Kaartisen artikkeli keskittyy Metsolat-televisiosarjan kahteen veljekseen, Heikkiin ja Ristoon, joiden selviytyminen ja hyvinvointi kietoutuvat työelämään ennen ja jälkeen laman alkua. Erkki tervehtyy päihderiippuvuudesta osittain yrittäjyyden kautta, kun samaisen yrittäjyyden (ja erityisesti siinä epäonnistumisen) kautta Riston elämä ajautuu kriisiin. Työttömyyden kuvataan tuottavan marginaalisuutta ja yrittäjämiehet kokevat heihin kohdistuvan valtavia paineita: he kantavat harteillaan paitsi omaa ja perheensä kunniaa myös tarinamalleja kansallisesta menestymisestä, ja siten myös kansallisesta epäonnistumisesta. Samalla veljesten kertomukset ovat myös tarinoita selviytymisestä, toivosta ja uusista aluista.

Noora Kallioniemi ja Elina Karvo puolestaan pohtivat Pekko Aikamiespoika -elokuvia samalta laman aikakaudelta. He suhteuttavat Pekon edustamaa positiivista joutilaisuutta julkiseen keskusteluun, jossa työttömyys alettiin nähdä yksilön henkilökohtaisena ominaisuutena. Lama-aikana yleistyi kuva, jossa työttömyys yhdistyi syrjäytymiseen. Julkinen puhe nosti ihanteeksi paitsi työssäkäyvän ja kansallista kilpailukykyä tuottavan myös itseään kehittävän ja valistuneen kansalaisen. Pekko on joutilas, mutta ei koe itseään syrjäytyneeksi ja hän osallistuu yhteisölliseen toimintaan ja kehittää itseään. Siten hän ystävineen itseasiassa haastaa kuvaa siitä, etteikö työtön voisi olla kokonaisvaltainen kansakunnan jäsen. Kysymykseksi Kallioniemi ja Karvo nostavatkin, olisiko meidän syytä tarkastella, miksi lienee tarkoitushakuista määritellä työttömyys syrjäytymistä automaattisesti tuottavaksi tekijäksi.

Tässä suhteessa Kallioniemen ja Karvon artikkeli suhteutuu ajankohtaiseen keskusteluun, jota on käyty ns. "ideologisesti työttömistä". Kun työttömyystuilla elävä kirjailija Ossi Nyman antoi haastattelun, jossa kertoi käyttävänsä työttömyystukia omien tavoitteidensa tavoitteluun (jotain muuta kuin unelma perinteisestä palkkatyöstä), leimahti kansallinen keskustelu, jossa joutilaisuudesta ja kilpailukykyä haittaavasta toiminnasta tehtiin kansakunnan pahe (ks. esim. Teittinen 2017). Onko meillä nykyään enää mahdollisuuksia Pekon positiiviseen joutilaisuuteen vai tarvitsemmeko kenties näitä hahmoja enemmän kuin koskaan?

Viimeinen tutkimusartikkeleista pohtii työelämän ulkopuolella olemista iän näkökulmasta. Sanna Kivimäki tuo esille, miten ikääntyvä väestö on tuonut uudenlaisia paineita myös mediakulttuurille ja sen tutkimukselle. Yhä edelleen vanheneminen liitetään marginalisoitumiseen, ja valtavirtaista toimijuutta on 
etsitty työikäisestä väestöstä. Kivimäen artikkeli keskittyy kriittisesti analysoimaan, millä tavoin mediatutkimuksen kenttä on suhtautunut vanhenemiseen ja millaisissa suhteissa ikääntyvät ovat saaneet huomiota tutkimuksessa, ja miten ikääntyviä voisi huomioida.

Katsauksissa kuva marginaalisuuden kokemuksista avautuu hieman erilaisiin suuntiin, mikä puolestaan avartaa numeron kokonaisuutta. Anna Kinnunen käsittelee, miten psyykkistä sairautta on esitetty Salatut elämät -televisiosarjassa. Hänen mukaansa Marianna Kurjen henkilöhahmo yhdistää seksuaalisuuden, vaarallisuuden ja rikollisuuden psyykkiseen sairauteen. Kinnunen kritisoi, miten tällainen stereotyyppinen kuvaus omalta osaltaan ylläpitää negatiivisia mielleyhtymiä mielenterveyden haasteista.

Maija Hirvonen ja Mikko Ojanen kirjoittavat sokean osallisuudesta audiovisuaaliseen kulttuuriin ja siitä, miten tämän kulttuurin saavuttamattomuus luo kokemuksia ulossulkemisesta. Heidän katsauksensa kysyy hyvin konkreettisesti, millaisia ääniä on sisällytetty ja sivuutettu suomalaisessa audiovisuaalisessa kulttuurissa yhtäältä kokemusten mahdollistamisen ja toisaalta niiden mahdollistamatta jättämisen kautta. He nostavat myös esille, miten marginaaleissa luodaan toimijuuden kokemuksia ja millaisia mahdollisuuksia olisi parantaa tilannetta entisestään.

Kaiken kaikkiaan numeron kokonaisuus on mielenkiintoinen paketti, jossa pohditaan, millaista suomalaisuus ja suomalainen audiovisuaalinen kulttuuri on 100-vuotiaassa maassa. Samalla numeron esille tuomat näkökulmat herättävät kriittisesti pohtimaan, mistä puhumme, kun käytämme termejä marginaalisuus ja kuuluminen, sisään ottaminen ja pois sulkeminen. Kaikissa numeron teksteissä on jollain tapaa läsnä marginaalissa olevien toimijuus, mikä korostaa marginaalisuutta prosessina, ei kohtalona tai kiveen hakattuna identiteettinä. Julkiseen puheeseen (ja kenties tutkimuksenkin termivalintoihin) pitäisi kenties saada ujutettua mukaan aktiivisempaa näkemystä marginaalisuudesta, jossa luodaan tilaa erilaisille toimijuuksille, liikkumisille ja tavoitteille riippumatta siitä, miten ne aina näyttäytyvät keskiöstä käsin. Näitä keskusteluja on mahdollista jatkaa myös Suomen juhlavuoden kunniaksi järjestettävässä seminaarissa "100 vuotta toiseutta kotimaisessa elokuvassa", joka järjestetään Helsingissä 24.11.2017.

Helsingissä 24.10.2017

Outi Hakola

\section{Lähteet}

Chand, Raghubir, Etienne Nel \& Stanko Pelc (toim.) (2017) Societies, Social Inequalities and Marginalization: Marginal Regions in the 21st Century. Cham: Springer.

Dennis, Rutledge M. (toim.) (2005) Marginality, Power and Social Structure: Issues in Race, Class, and Gender. Oxford: Elsevier.

Ferguson, Russell, Martha Gever, Trinh T. Minh-ha \& Corner West (toim.) (1990) Out There: Marginalization and Contemporary Cultures. Cambridge: The MIT Press.

Hokka, Jenni (2014) Kakkoselta kaikelle kansalle: Kuulumisen politiikka YLE TV2:n arkirealistisissa sarjoissa. Tampere: Tampere University Press.

Kanerva, Arla 2017. Elämäkertoja ilmestyy tänä syksynä poikkeuksellisen paljon, ja niistä poikkeuksellisen suuri osa kertoo miehistä - kustantaja: "Meille ei tarjota naisista kertovia elämäkertoja". Helsingin Sanomat 13.8.2017. 
Kivi, Iikka (2017) Päivitys. Facebook 25.5.2017. <https://www.facebook.com/likkaKivi/ posts/1404036176346725> (linkki tarkistettu 20.10.2017).

Lee, Jung Young (1995). Marginality: The Key to Multicultural Theology. Minneapolis: Fortress Press.

Pelc, Stanco (2017) Marginality and marginalization. Teoksessa Chand, Raghubir, Etienne Nel \& Stanko Pelc (toim.) Societies, Social Inequalities and Marginalization: Marginal Regions in the 21st Century. Cham: Springer, 13-28.

Rodríquez Garzia, Magaly \& Amandine Lauro (2016) Belgian History and the Making of Marginality and Subalternity. Journal of Belgian History Vol. 46:1, 14-39.

Teittinen, Paavo (2017) Kirjailija kertoi olevansa "ideologisesti" työtön ja kikkailevansa tukia TE-toimisto katkaisee tuet ja aloittaa poikkeuksellisen selvityksen. Helsingin Sanomat 13.10.2017.

Me (1.4.2017). Miesten syrjäytyminen alkaa jo peruskoulussa - "On jumiuduttu kotiin jopa kahdeksi vuodeksi". <https://yle.fi/uutiset/3-9513404> (linkki tarkistettu 20.10.2017).

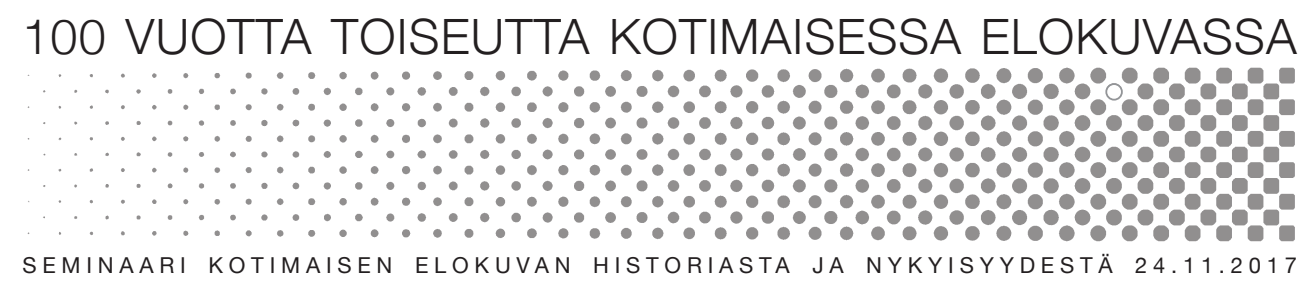

KINO K-13 KANAVAKATU 12 HELSINKI
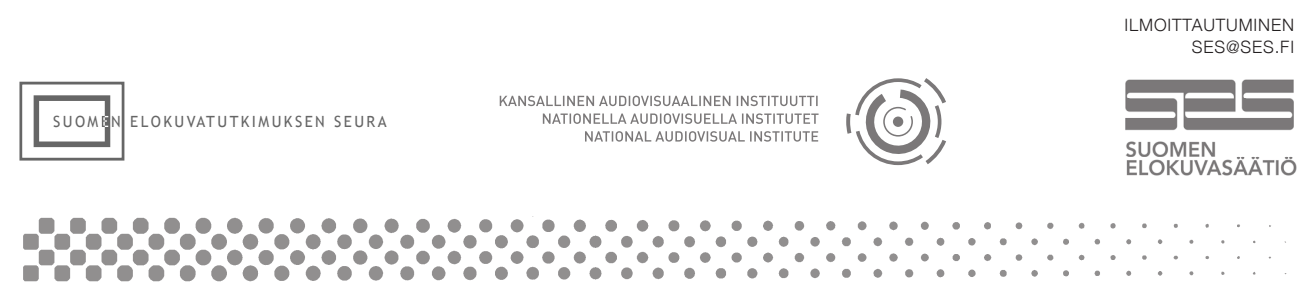

Toiseus suomalaisessa elokuvassa

Suomi täyttää sata vuotta jo varsin heterogeenisenä kokonaisuutena. Kotimainen elokuva on kuitenkin viime aikoihin saakka kuvannut Suomea varsin yhtenäisenä kansakuntana. Vähemmistöt ovat pitkään näyttäytyneet lähinnä vain suomalaisuuden eksoottisena lisänä. Kansallisuus ei kuitenkaan ole koskaan monoliittinen kokonaisuus, siihen on aina sisäänrakennettu monenlaisia toiseuksia. Ne ilmenevät sisäisinä ristiritaisuuksina, joskus tukahdutettuna oireillen.

Toiseuteen sisältyy myös vahva dramaturginen potentiaali. Päähenkilön sosiaalinen rooli ja kerronnallinen merkitys rakentuvat sen kautta, että hänellä on sekä erilaisia läheisiä, ystäviä ja auttajia että kilpailijoita ja vastustajia. Kaikki nämä edustavat tavalla tai toisella sekä samuutta että toiseutta päähenkilöön nähden. Yksi dramaturgian peruskysymyksiä on luoda tällaisesta joukosta keskenään mielenkiintoisella tavalla kontrastoivia henkilöitä. Kansallisuus, etnisyys, luokkaerot, sukupuoli, sukupuolinen suuntautuminen ja monet muut tekijät ovat joko hyvässä tai pahassa toimineet merkkeinä toiseudesta, johon katsoja päähenkilöiden ohella joutuu elokuvakokemuksen myötä ottamaan kantaa.

Toiseus suomalaisessa elokuvassa -seminaarissa käsitellään toiseuden kysymyksiä läpi suomalaisen elokuvan historian. Erityisen tarkastelun kohteena se miten toiseus tarinassa asemoidaan ja miten se puolestaan ohjaa katsojan suhtautumista.

- Henry Bacon

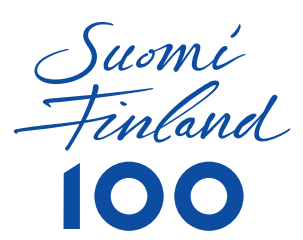

PÄÄKIRJOITUS • Outi Hakola: Sisään laskemisen ja pois sulkemisen rajamailla, 3-8. 


\section{VUOTTA TOISEUTTA KOTIMAISESSA ELOKUVASSA}

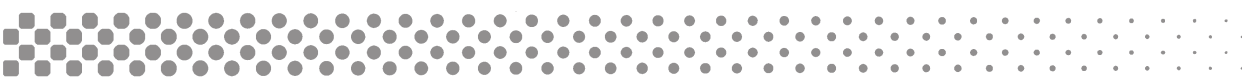

Seminaarin avaus

Matti Lukkarila (KAVI), Lasse Saarinen (SES), Jaakko Seppälä (SETS)

12.05

Johdatus seminaarin teemaan

Professori Henry Bacon, Helsingin yliopisto (15

12.20 Keskellä ja sivussa: toiseuden tarkastelua tapauksien Wrede ja Kotschac kautta Professori emeritus Tytti Soila, Tukholman yliopisto (40')

Toiseutta kautta aikojen

Erikoistutkija Antti Alanen, KAVI (20')

Kansakuntien tuolle puolen! Jörn Donner ja unelma eurooppalaisesta elokuvasta Professori Anu Koivunen, Tukholman yliopisto (20')

KESKUSTELUA

TAUKO

Näkökulmia toiseudesta fiktioelokuvassa ja dokumenttielokuvassa Professori Elina Knihtilä ja TT Jouko Aaltonen (40')

KESKUSTELUA

15.30 Toinen Suomi: kulttuurihistoriallinen näkökulma Professori Hannu Salmi, Turun yliopisto (40')

\section{KESKUSTELUA}

Aki Kaurismäen ironinen minimalismi ja yksinäisyyden representaatiot Dosentti Jaakko Seppälä, Helsingin yliopisto (20')

Humoristisista takaa-ajoista hapuileviin kohtaamisiin.

Maahanmuuttajat 2000-luvun suomalaisissa fiktioelokuvissa

FT Kaisa Hiltunen, Jyväskylän yliopisto (20')

"Sä nyt pääset huipulle kaikessa mihin sä vaan ryhdyt."

Uusliberalistinen menestystarina ja nuori 2000-luvun elokuvassa

FT Tommi Römpötti, Turun yliopisto (20')

KESKUSTELUA 